\title{
Flavivirus Neurotropism, Neuroinvasion, Neurovirulence and Neurosusceptibility: Clues to Understanding Flavivirus- and Dengue-Induced Encephalitis
}

\author{
Myriam Lucia Velandia ${ }^{1}$ and Jaime E. Castellanos ${ }^{1,2}$ \\ ${ }^{1}$ Grupo de Virología, Universidad El Bosque \\ ${ }^{2}$ Grupo Patogénesis Viral, Universidad Nacional de Colombia Bogotá, \\ Colombia
}

\section{Introduction}

Viral infections of the nervous system (NS) can be caused by many types of viruses, including rhabdoviruses, alpha and beta herpes viruses, retroviruses, picornaviruses, arenaviruses and flaviviruses (van den Pol, 2006) The replication of these viruses can occur both in neurons and in non-neuronal cells and each type of cell responds differently (Griffin, 2003). The final result of these infections is the alteration of function of the nervous system.

Flaviviruses are single-stranded positive sense RNA viruses of epidemiological and neurological importance because the majority of them infect the NS, causing severe damage to its function (Figure 1)(Lindenbach et al., 2007). The flaviviruses that most frequently infect nervous tissue are Japanese encephalitis virus (JEV), West Nile virus (WNV), Murray Valley encephalitis virus (MVEV) and tick-borne encephalitis virus (TBEV). However, other members of this family, such as yellow fever virus (YFV) and dengue virus (DENV), which preferentially infect hepatocytes and immune cells like monocytes and macrophages, can acquire the capacity to enter and infect nervous tissue (Misra et al., 2006).

Infection with flaviviruses occurs via an interaction between viral envelope (E) proteins and molecules on the cellular surface that act as receptors that promote endocytosis of the virus (Chambers et al., 1990; Lindenbach et al., 2007; van der Schaar et al., 2007, 2008). This initial interaction partially defines the virus tropism; however, the mechanisms that determine and promote infection of nervous tissue with neurotropic flaviviruses are not completely understood (Chambers \& Diamond, 1999; McMinn, 1997). Furthermore, nervous tissue infected with DENV is of particular interest because although this virus is not neurotropic, it can induce alterations in nervous system function that are being reported with increasing frequency. In some cases, virus-specific IgMs have been isolated from the cerebrospinal fluid, which suggests the presence of the virus in the NS (Domingues et al., 2008; Lum et al., 1996).

In severe cases of dengue fever, neurological alterations including encephalitis, encephalomyelitis, transverse myelitis, flaccid paralysis, Guillain-Barre Syndrome, cerebrovascular accident and behaviour disorders have been reported (Domingues et al., 
2008; Mathew \& Pandian, 2010; Misra et al., 2006; Solomon, 2003, 2004). Frequently, neurological signs manifest as a consequence of viral infection in organs such the liver (encephalopathies) (Gulati \& Maheshwari, 2007; Row et al., 1996). Despite the fact that little is known about the mechanisms that favour DENV infection of nervous tissue (Chien et al., 2008; Kumar et al., 2008; Malavige et al., 2007), it has been postulated that the individuals' age, genetic background and immune status, in addition to the viral serotype and genotype, may explain both the ability of the virus to infect the NS and the appearance of neurological manifestations as a result of this virus infection. This chapter will review the interactions between nervous tissue and certain flaviviruses, including DENV, such as neuroinvasion, neurotropism, neurovirulence and neurosusceptibility.

\section{A. Genomic RNA of Flavivirus}

5' UTR STRUCTURAL PROTEINS NON STRUCTURAL PROTEINS

\section{B. Polypeptide Translation}

\begin{tabular}{ll|l|l|l|l|l|l|l|l|l}
$\mathrm{NH}_{2}-\mathrm{C}$ & $\mathrm{prM}$ & $\mathrm{E}$ & 1 & $2 \mathrm{~A}$ & $2 \mathrm{~B}$ & 3 & $4 \mathrm{~A}$ & $4 \mathrm{~B}$ & 5 & $\mathrm{COOH}$
\end{tabular}

\section{Organization of structural proteins in flavivirus}

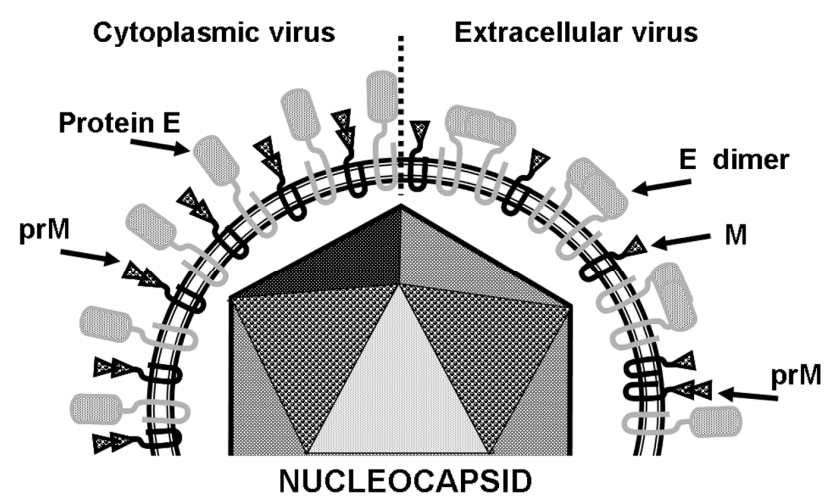

Fig. 1. Schematic organization of genome and polyprotein of a flavivirus. A. The flaviviruses are enveloped single strand RNA viruses with a unique open reading frame coding for both structural and non structural genes. B. Diagram of entire translated polyprotein which must be cleaved by viral and cellular proteases to release mature and active proteins. C. Schematic representation of final disposition of structural proteins in the virions. After proteolytic cleavage or prM, glycoprotein E exposes its homodimerization domains to activate the cellbinding site. Core protein specifically encapsidates the recently synthesized genomic RNA to form the nucleocapsid.

\section{Neuroinvasion}

Neuroinvasion is the ability of viruses to enter nervous tissue and cause neurological alterations. The majority of viruses in the Flavivirus genus are transmitted via the bite of an 
arthropod vector (mosquito or tick), and once inoculated in the dermis, these viruses spread to infect target cells such as dendritic cells or monocytes/macrophages or enter directly into the lymph nodes, muscles, liver, spleen or nervous system via nerve endings (Chambers \& Diamond, 2003; McMinn, 1997). In some cases during infection with these viruses, the blood-brain barrier (BBB) is disturbed as a result of cytokines and chemokines that favour the entry of WNV and JEV into nervous tissue (Chambers \& Diamond 2003; Chaturvedi et al., 1991) (Figure 2).

\subsection{The blood-brain barrier disruption and axonal transport}

The BBB is formed by specialised endothelial cells, surrounded by a basal lamina, pericytes, astrocytes and neurons that together form the neurovascular unit (NVU). This structure acts as a physical and metabolic barrier that restricts the type of nutrients and molecules that can enter the cerebral parenchyma (Banerjee \& Bhat, 2007; Calabria \& Shusta, 2006; Cardoso et al., 2010). Inter-endothelial junctions formed by membrane proteins present at tight junctions (claudins, occludins and Juctional Adhesion Molecules (JAM) and adherens junctions (cadherins and catenins) filter nutrients and metabolites and regulate the passage of immune cells into nervous tissue (Cardoso et al., 2010).

However, during infection with neurotropic flaviviruses such as WNV, JEV and MVEV, the over-expression of cytokines, such as tumour necrosis factor-alpha (TNF-alpha), or enzymes, such as matrix metalloproteinase (MMP), affects the permeability of the endothelium and permits the entry of viruses into the cerebral parenchyma (Chambers \& Diamond, 2003). Wang et al. (2004) reported that during WNV infection, the over-expression of TNF-alpha and interleukin 6 (IL-6) affects the integrity of the BBB because they alter expression of the proteins responsible for inter-endothelial junctions (Wang et al., 2004). Additionally, MMP enzymes digest the basal lamina, weakening the interactions between endothelial cells and other elements forming the NVU (Cardoso et al., 2010; Petty \& Lo, 2002; Wang et al., 2004), favouring the entry of viral particles or infected leukocytes into the cerebral parenchyma and facilitating the spreading and replication of the virus in nervous tissue (Wang et al., 2004).

Additionally during infection, endothelial cells are activated and overexpress cellular adhesion molecules that favour the transmigration of immune cells into the cerebral parenchyma, such as E-selectin, VCAM-1 and ICAM-1 (Shen et al., 1997; Verna et al., 2009). For example, the overexpression of ICAM-1 promotes the adhesion and diapedesis of infected and activated leukocytes that can enter and alter the brain. These cells can also amplify the infection, acting as Trojan horses that introduce viral particles into nervous tissue (Ben-Nathan et al., 1996; Cardosa et al., 1986; King et al., 2007). Infection with flaviviruses and the signalling induced by some cytokines expressed extraneurally during such an infection can activate macrophages and microglial cells. These cells then acquire an antigen-presenting phenotype and produce and spread pro- and anti-inflammatory molecules such as IL-6, IL-1 $\beta$, IL-10, TNF-alpha, type I and II interferon (IFN) and the monocytes chemotactic protein (MCP-1) in the brain microenvironment (Ghoshal et al., 2007), which promotes the disturbance of the endothelium and increases and sustains the activation of glial cells, promoting the infiltration of leukocytes (Muñoz-Fernández \& Fresno, 1998) Another aspect that contributes to the disturbance of the $\mathrm{BBB}$ and the transport of flaviviruses into the cerebral parenchyma is the infection of endothelial cells (Avirutnan et al., 1998), which allows replication of the virus and its subsequent movement toward the cerebral parenchyma (Liu et al., 2008; Lopes et al., 2007; Mathur et al., 1992; Mishra et al., 2009) (Figure 3). 


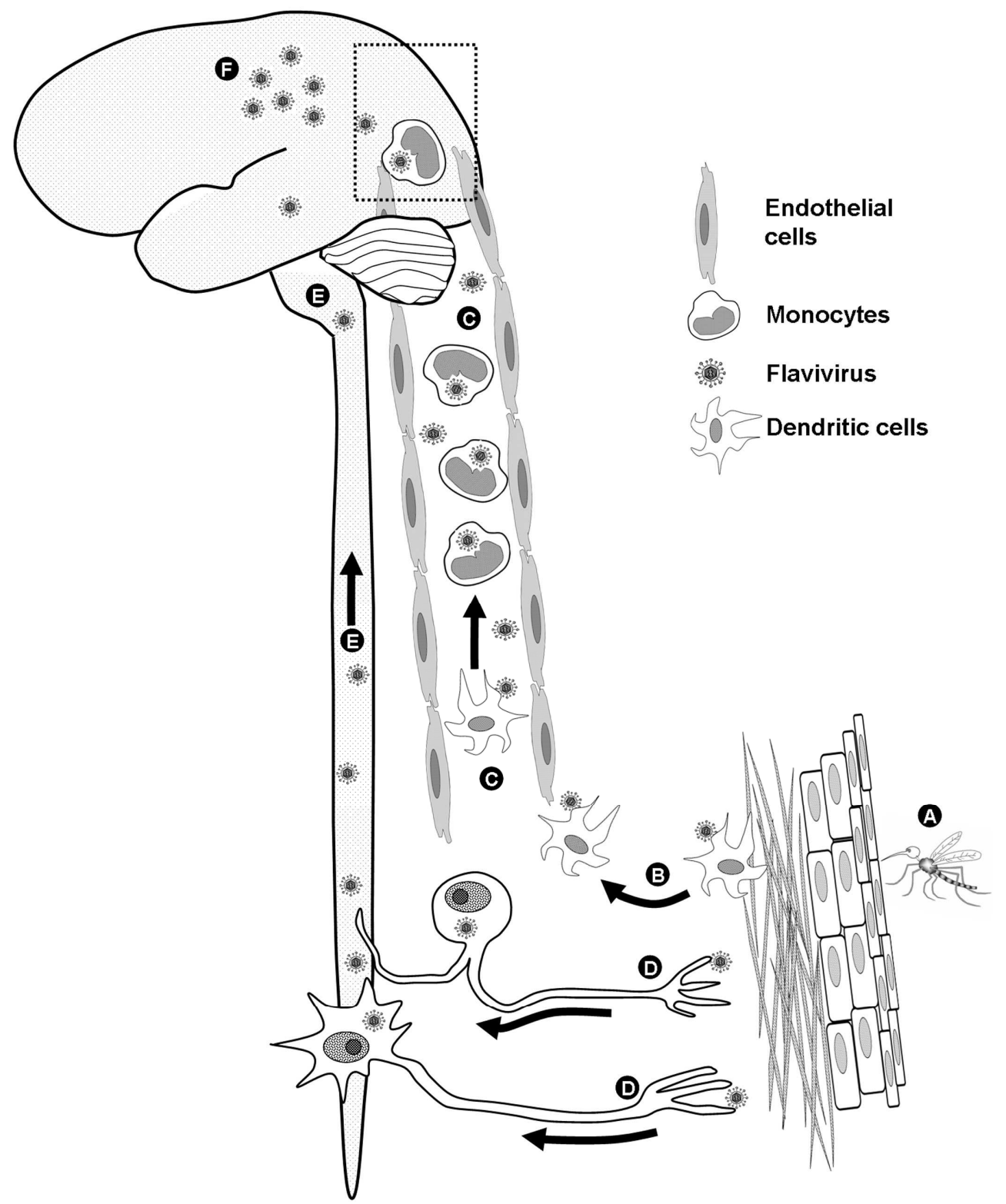

Fig. 2. Mechanisms for flavivirus entry into nervous systmem during neurologic disease. Neurotropism could be explained by direct binding of virus with neurons or ability of neurons to replicate the virus, while neuroinvasión and neurovirulence depends on ability of virus to enter to CNS and disrupt the brain architecture or function. A. - Flavivirus inoculation by an arthropod bite in the dermis. B. - Dendritic cells or Langerhans cells take the inoculated virus and migrates to lymph nodes to infect other immune cells. C. - Virus- 
free or cell-associated virus spreading using hematogenous pathway to enter CNS and infect neurons and glia. D. - Virus capture and spreading by sensory and motor peripheral fibers. Virus is transported by retrograde axonal transport to CNS, and E. - spread following connecting neurons. F. - Then; virus can infect neighborhood neurons affecting its metabolism and function. During extraneural infection, immune cells produce cytokines and chemokines, which induce adhesion molecules expression in brain endothelial cells, favouring rolling of monocytes and macrophages. In addition to cells, the over expression of pro-inflammatory mediators and proteolytic enzymes result in an increase in blood-brain barrier permeability (see explanation of inset box in Figure 3).

However, infection and the damage to endothelial cells in vivo is not always evident, and Liou and Hsu (1998) demonstrated that JEV passes through brain endothelial cells via transcytosis (Liou \& Hsu, 1998), suggesting that flaviviruses can exploit a diversity of mechanisms to penetrate nervous tissue. Other routes used by flaviviruses to enter the NS include the hematogenous route and axonal transport. The haematogenous route is the most likely dispersion route of various viruses, including flaviviruses, because these viruses, after being inoculated by mosquitoes or ticks, infect monocytes/macrophages, dendritic cells and Langerhans cells, which then transport viruses to a second cell type, such as epithelial, endothelial, fibroblast or muscle cells (Chambers \& Diamond 2003; Lindenbach et al., 2007).

WNV, JEV and TBEV also utilise axonal retrograde or anterograde transport in olfactory epithelial neurons and motor neurons to penetrate and spread within the central nervous system (CNS) (Charles et al., 1995; Monath et al., 1983; Ramos et al., 1994; Sriurairatna et al., 1973), and peripheral nervous system (PNS) (An et al., 2003; McMinn et al., 1996; Samuel et al., 2007a; Silvia et al., 2003). Samuel et al. (2007b) using in vitro and in vivo infection models demonstrated that WNV enters to CNS and is transported efficiently using axonal transport in spinal medullary neurons and superior cervical ganglion neurons. Additionally, they demonstrated that in a hamster model, after viral inoculation and sciatic nerve transection, animals exhibited neurological alterations such as paralysis and prostration, suggesting that WNV utilises both the nervous and hematogenous routes to penetrate and replicate in nervous tissues (Samuel et al., 2007b).

\subsection{DENV neuroinvasion}

With regard to infection of the NS by DENV, it has been reported that this virus can infect NS cells in vitro and in vivo and could use axonal transport to spread inside the brain. Moreover, it has been demonstrated that in vivo infection with DENV can alter the integrity of the BBB (Chaturvedi et al., 1991), which has been associated with high levels of MMP-9 in plasma. This enzyme can degrade the basal lamina of the NVUs and facilitate the free passage of the virus and infected leukocytes into the cerebral parenchyma (Luplertlop et al., 2006). In animal models, NS infection by DENV has been reported after the virus was tissueadapted, as reported by Cole and Wisseman (1969) and Sriurairatna et al. (1973). These authors achieved infection and virus production in tissue, accompanied by neurological signs associated with infection, such as paralysis of the posterior limbs. This infection was achieved after adapting a DENV strain via numerous passages in mice brains (Cole \& Wisseman, 1969; Sriurairatna et al., 1973). 


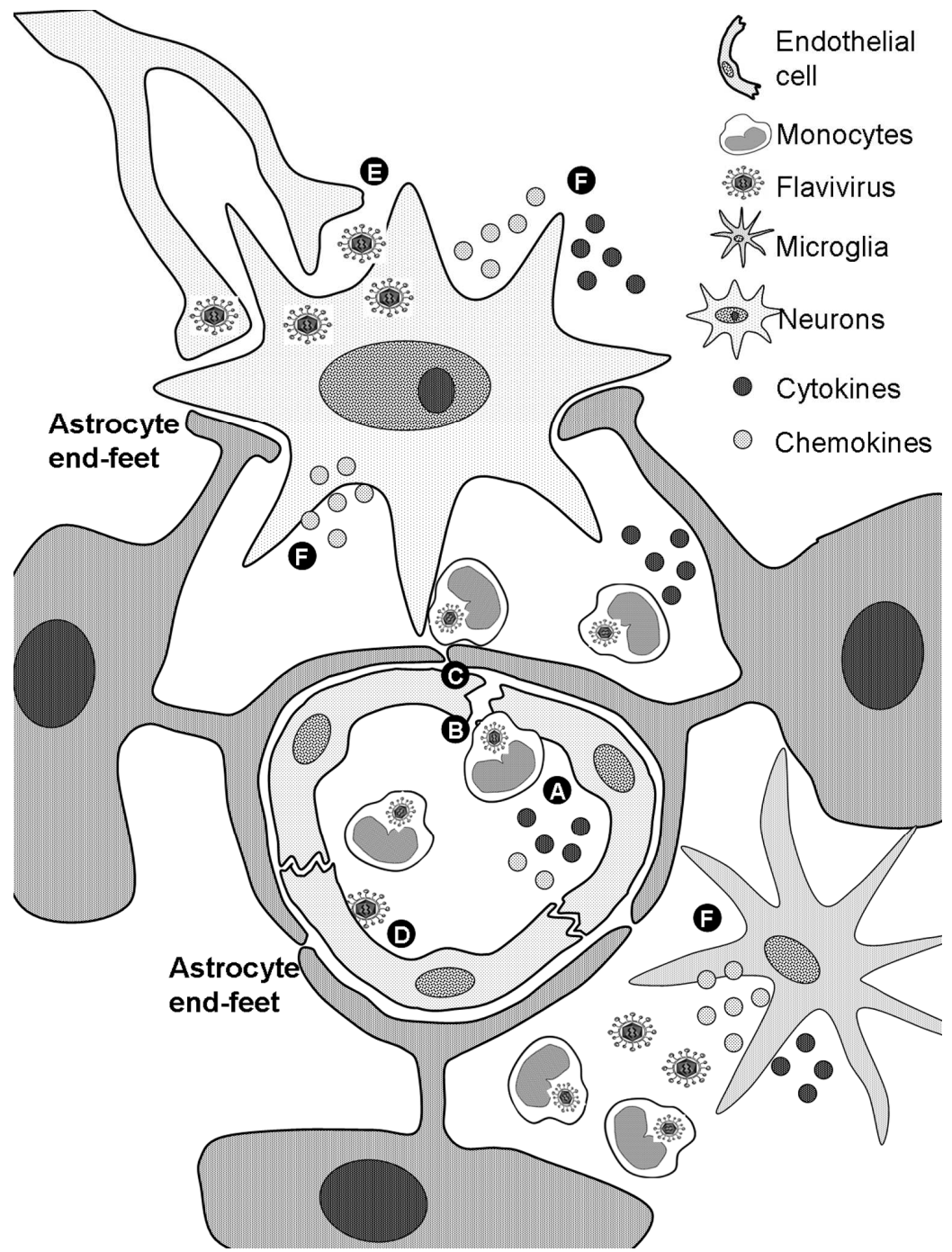

Fig. 3. Diagram of a neurovascular unit, a capillary enclosed in astrocyte end-feet during a nervous system infection by a flavivirus. A. - Infected and non-infected immune cells secretion of cytokines and chemokines. B. - Disruption of thigh junctions that seal the pathway between the capillary endothelial cells, caused by cells and inflammatory mediators. C. - Transcytosis of infected cells to brain parenchyma. D. - Direct infection of brain endothelial cells by flavivirus. E. - Virus neuronal infection by neighbor infected neurons. F. - Secretion of cytokines and chemokines by infected neurons and glial cells, causing change of structure and function of nervous cells.

Desprès et al. (1996 and 1998) also reported nervous tissue infection in 2-day-old mice after viral adaptation of a DENV-1 strain in nervous tissue and mosquito cells. This model of 
neuroinfection was the first to suggest that neurological alterations exhibited by infected animals, such as paralysis of posterior limbs, are principally associated with the death of infected neurons (Desprès et al., 1996, 1998). Another model of nervous tissue infection was developed by An et al. (2003), who infected young adult SCID mice (severe combined immunodeficiency) with an non adapted DENV-2 strain; these animals developed high viral titres in their nervous tissue, and viral particles were observed in spinal medullary motor neurons, axons and ependymal cells (An et al., 2003), using transmission electron microscopy, which suggests that DENV can penetrate and infect CNS and PNS neurons using axonal transport. Finally, it has been reported that DENV, regardless of whether it is adapted to nervous tissue, can infect a low proportion of primary neurons or cell lines in vitro (Desprès et al., 1996; Imbert et al., 1994; Ramos et al., 1994, 1998), thus demonstrating DENV weak neurotropism.

This evidence demonstrates that neuroadapted DENV, can infect the brain and can utilise axonal transport to enter and spread throughout the nervous system (An et al., 2003; Desprès et al., 1998; Liou \& Hsu, 1998; Lum et al., 1996), Nevertheless, this virus continues to be classified as a non-neurotropic virus, and the elements that confer the capacity to enter, infect and spread in nervous tissue in this virus are completely unknown.

\section{Neurotropism}

The ability of some viruses to infect and replicate in neurons is called neurotropism and is determined by viral and cellular factors. Mostly virus determinants are associated with envelope glycoprotein gene mutations that favour interactions between the virus and molecules on the neuron surface. These interactions promote the fusion of the virus with the plasma membrane and can also trigger endocytosis or transcytosis of the virus. A wellknown example of viral neurotropism is that mediated by glycoprotein $G$ of the rabies virus (a highly neurotropic virus), which interacts with the neurotrophin low-affinity receptor, the neural cell adhesion molecule or the nicotinic receptor present in muscular and neuron cells to infect cells. The interaction of rabies virus protein $G$ with some of these molecules promotes virus entry and replication in the nervous system (Lafon, 2005).

\subsection{Viral and cellular proteins}

The virus and cell interactions occur first with molecules that act as low-affinity receptors to bring virus closer to membrane, and then viral co-receptors bind to proteins on the viral surface and promote infection, which can be mediated by endocytosis or through the fusion of membranes such that the nucleocapsid is released into the cytoplasm. The use of coreceptors is common in many different viruses. The human immunodeficiency virus uses co-receptors to infect $\mathrm{T}$ lymphocytes and macrophages via the CD4 receptor and the CCR5 and CXCR4 molecules (Moiser, 2009).

In flaviviruses, the envelope protein (E) is the principal component of the virion surface. It participates in the recognition and subsequent binding to the receptor and the fusion of the virus with the cell membranes (Lindenbach et al., 2007). This protein is formed by three beta-barrel domains known as domains I, II and III, and these last two are responsible for interacting with putative receptor molecules (Pastorino et al., 2010). Variations in the amino acid sequence in domains II and III, which are associated with the lack of proofreading 
activity of the flavivirus RNA polymerase, bear directly upon the changes of viral tropism and can promote the neurotropism of flaviviruses including DENV (Lee et al., 2006a).

The molecules that have been reported as possible receptors for DENV, JEV, WNV and TBEV in different cell populations include ICAM-3 (Jindadamrongwech \& Smith, 2004), CD209 (DC-SIGN) (Tassaneetrithep et al., 2003), DC-SIGNR (Davis et al., 2006), integrins (Chu \& Ng, 2004), the mannose receptor (Miller et al., 2008), HSP70 and HSP90 (Das et al., 2009; Reyes del Valle et al., 2005), the laminin receptor (Tio et al., 2005) and heparan sulphate (HS) (Germi et al., 2002) among others (Barba-Spaeth et al., 2005; Upanan et al., 2008). It seems that HS favours the attraction and recruitment of viral particles to the cellular surface, thus favouring the direct entry of the virus or interaction with a second receptor molecule (Germi et al., 2002; Lee et al., 2002, 2004, 2006b). Additionally, in human (SK-N$\mathrm{SH}$ ) and murine (N1E-115) neuroblastoma cell lysates, the presence of a $65 \mathrm{kDa}$ protein that binds specifically to DENV-2 has been reported (Ramos et al., 1997), and these findings suggest that neuronal cells express a receptor that permits the binding of the virus with these cell membranes; however, the characterisation of this protein has not been reported.

As was previously stated, the E flavivirus protein partially determines cellular tropism. However, the molecular determinants that promote the entry into susceptible cells are not well known, and the mechanisms that define their neurotropism are even less clear (Lobigs et al., 1990). So far, the RGD Motif (Arg-Gly-Asp), present in the E protein of JEV, YFV, TBEV and WNV, has been identified as being responsible for promoting the interaction between these viruses and integrins present on the surface of susceptible cells. This was demonstrated by modification of position 390 of the E protein of MVEV, which changes the tropism and virulence of this virus. Thus, this amino acid motif is proposed as the main site of interaction between flaviviruses and their viral receptors (Becker, 1990; Lee \& Lobigs, 2000; Lobigs et al., 1990). However, the RGD motif has not been identified in the E protein of DENV, which suggests that this virus possesses different domains or mechanisms for interacting with receptor molecules.

\subsection{DENV neurotropism}

Various authors have reported that during in vitro or in vivo passages associated with the adaptation of DENV, mutations occur throughout the genome, primarily in glycoprotein E, which seemingly confers neurotropism and the ability to enter nervous tissue and cause neurological alterations. For example, the Glu ${ }_{126}$ Lys change in the DENV-2 E protein changed the virus tropism and conferred the capacity to infect nervous tissue (Gualano et al., 1998). Similarly, the mutations Asp ${ }_{390} \mathrm{His}$ and Phe ${ }_{402} L \mathrm{Lu}$ in DENV-4 E protein conferred a neurotropic and neurovirulent phenotype on the virus (Bray et al., 1998; Kawano et al., 1993; Sanchez \& Ruiz, 1996). These findings suggest that for DENV to acquire a neurotropic phenotype, certain variations must occur in the sequence located in specific regions of the $\mathrm{E}$ protein (Desprès et al., 1996; Lee et al., 2006a). However, mutations in non-structural viral proteins could also determine the success of the infection, particularly the replication of the virus in neurons (Duarte dos Santos et al., 2000). Consequently, it should be determined whether the neurotropism of adapted DENV depends on the viral serotype used and the type of cell to which the virus is adapted. Additionally, the mechanisms of DENV transport and dispersion throughout the nervous tissue and whether these mechanisms depend on 
changes in the viral genome acquired during the process of neuroadaptation should be evaluated.

\section{Neurovirulence}

Neurovirulence is the capacity of viruses to cause disease and alterations in the nervous system and can be affected by both viral and host-related factors. The viral factors that affect neurovirulence are viral serotype and genotype. Beasley et al. (2002) reported that genotypes I and II of WNV, which are very similar in sequence, cause different neurological alterations in mice and hamsters (Beasley et al., 2002).

\subsection{Serotypes and genotypes}

The dengue serocomplex is formed by 4 viral serotypes that possess a high genome homology and all cause dengue symptoms. However, it has been demonstrated that the genomic differences among DENV serotypes and genotypes induce clinical manifestations of the disease that vary in intensity, as has been shown for DENV-2 and DENV-3, which have been associated mainly with haemorrhagic symptoms and cases of severe dengue in some patients (Clyde et al., 2006; Tsia et al., 2009).

For example, the best-studied genotypes of DENV-2 are the Asian and American genotypes. When the Asian strain started circulation in the American continent, it was caused serious dengue outbreaks with haemorrhagic symptoms in patients with primary infections who were from Central and South American countries (Clayde et al., 2006). The Asian genotype is frequently associated with severe dengue and haemorrhagic symptoms in Asian patients, and experimentally, this genotype is more virulent and replicates with higher efficiency in macrophages, while the American genotype is associated with signs of dengue fever and its replication is slower in cultured macrophages (Barreto dos Santos et al., 2002; Guzmán et al., 2002a; Rico-Hesse et al., 1997).

These differences could partially explain the changes in symptoms exhibited by patients infected with DENV. When the genotype sequences were compared, significant differences were found in the $5^{\prime}$ and $3^{\prime}$ untranslated regions (UTR) of the genomic RNA, and it was observed that the $3^{\prime}$ UTR of the Asian genotype generates secondary structures that permit better interaction with the viral RNA polymerase and enhance its processivity. This difference could explain the efficiency of virus replication and virus production in infected cells with this genotype, which in turn could be related to the inefficiency of the immune system to control and eliminate this virus (Cologma \& Rico-Hesse, 2003; Leitmeyer et al., 1999).

Additionally, it has been reported that genotype I of DENV-3 can induce different symptoms in infected mice, when was intracerebrally inoculated. An effective infection was observed with high viral titer detected in tissue. Infiltration of monocyte cells into the cerebral parenchyma was also detected, as was the appearance of neurological symptoms such as meningo-encephalitis and paralysis associated with neuronal degeneration. In contrast, intracerebral inoculation of mice with genotype III induced a less intense immune response, with less tissue damage and low viral production (Ferreira et al., 2010), confirming that differences among genotypes and serotypes can be related to flavivirus virulence. 
Beyond viral factors, the neurovirulence caused by flaviviruses can be related to the type of immune response that the individual generates against infection at the local and systemic levels. This response is similar among flaviviruses, although DENV and YFV mainly induce alterations in vascular permeability and in coagulation (Avirutnan et al., 2010). The immune response that occurs in nervous tissue during flavivirus infection varies in intensity and can support the control and clearence of the virus and establish a neuroprotective state that stimulates the repair of tissue damaged by the infection (Griffin, 2003). To promote virus clearance, monocytes and lymphocytes enter the cerebral parenchyma, attack infected cells, and release soluble mediators, which stimulate and maintain the local immune response activating astrocytes, microglia and the cerebrovascular endothelium. Additionally, the infected or damaged neurons themselves can express and release some of these mediators (Chakraborty et al., 2010), amplifying the local immune response.

\subsection{The host factor: Immune and nervous system}

As was mentioned above, the activated cerebrovascular endothelium can facilitate the passage of $\mathrm{T}$ and $\mathrm{B}$ lymphocytes and macrophages and allow the leakage of soluble factors and toxins that increase inflammation and damage the cerebral parenchyma, causing neuron death (Less et al., 2006; Lin et al., 2002; Wrona, 2006). Inflammation of nervous tissue is associated with the activation of astrocytes and microglia, as indicated by morphological changes and changes in the expression profile of adhesion molecules, cytokines and interleukins (TNF-alpha, IL-1 $\beta$, IL-6, IL-10, IFNs, MCP-1 and TGF- $\beta$ ), which combined with factors secreted by infiltrating immune cells, can increase the nervous system damage (Muñoz-Fernández \& Fresno, 1998). The activation of glial cells is partially due to their infection by flaviviruses. For example, astrocytes infected with WNV express the chemokine CXCL10 and other neuroinflammatory and neurotoxic molecules that can increase nervous system injury and induce the death of both infected and uninfected neurons. These data suggest that the activation of glial cells depends on viral replication and that the signalling induced by some inflammatory mediators within the nervous tissue can increase the neuropathogenesis caused by WNV (Van Marle et al., 2007) and other flaviviruses.

Immune cells that infiltrate nervous tissue are mainly CD4+ and CD8+ T lymphocytes and macrophages. CD4+ lymphocytes producing IL-12 stimulate the cytotoxic activity of CD8+ lymphocytes that arrive to the nervous tissue. These lymphocytes secrete proinflammatory mediators such as IFN-gamma, TNF-alpha and IL-6 that alter tissue homeostasis when expressed consistently during the infection (Chaturvedi et al., 2000; Sánchez-Burgos et al., 2004; Swarup et al., 2007). Additionally, CD8+ lymphocytes embedded in the tissue promote the death of both infected and uninfected cells via the release of perforin and granzymes and the expression of Fas ligand (FasL) (Courageot et al., 2003; Marques-Deak et al., 2005; Mellor \& Munn, 2006; Rempel et al., 2004, 2005). Lastly, infiltrating macrophages modulate the type of immune response that occurs in the tissue during infection and can clear free viral particles and infected and damaged cells present in the tissue, although these cells can also seemingly promote the entering of some flaviviruses, acting as Trojan horses by releasing viral particles within the nervous tissue (Chaturvedi, 2006; Chaturvedi et al., 2006).

Finally, neurotropic flaviviruses as well as non-neurotropic flaviviruses preferably infect neurons in vitro and in vivo (Chambers \& Diamond, 2003; Johnson \& Roehring, 1999; Samuel \& Diamond, 2006; Shrestha et al., 2003). Nevertheless, it has been reported that other 
nervous tissue cells such as oligodendrocytes, astrocytes and microglial cells (Chen et al., 2000; Jordan et al., 2000) may be susceptible to infection. The cellular, metabolic and molecular factors that increase the susceptibility of neurons to flaviviruses are unknown. Additionally, it has been reported that infection with some flaviviruses, including DENV, induces death in infected neurons. This response may be mediated by TNF-alpha, the Fas/FasL complex or the release of cytochrome $\mathrm{c}$ and the presence of free radicals; during this process, caspases 3, 8, and 9 have been found to be activated (Courageot et al., 2003; Marianneau et al., 1998; Samuel et al., 2007a). Thus, cell death in nervous tissue, such as neurons, has been associated with the development of neurological alterations resulting from infection.

\section{Neurosusceptibility}

Neurosusceptibility refers to the vulnerability of a host to neurological alterations during an infection with neurotropic viruses. This vulnerability can be affected by the age, species, immune status and genetic background of the individual.

\subsection{Age}

Using animal models, it has been demonstrated that physiological immaturity increases the susceptibility of the nervous system to WNV and JEV infection (Ogata et al., 1991; Weiner et al., 1970). For example, JEV infects neurons in the cortex, hippocampus and brainstem of 2day-old mice, but the areas susceptible to infection and the numbers of infected neurons diminish as age increases. This resistance to infection is maintained, even if previouslyinfected neonatal neurons are implanted in animals greater than 14 days old. Similarly, the mortality of rats infected with JEV is $100 \%$ when they are inoculated between 2 and 12 days after birth but diminishes to $50 \%, 8.3 \%$ and $0 \%$ when they are inoculated at 13,14 and 17 postnatal days. These results demonstrate that the neuronal and physiological maturity of nervous tissues is determining factors in favouring infection and neuronal alteration (Ogata et al., 1991; Weiner et al., 1970).

With respect to DENV-2 infection, Guzmán et al. (2002b) reported that children between the age of 3 and 4 years old were more vulnerable to developing symptoms of dengue compared to older children and adults (Guzmán et al., 2002b). This vulnerability is due principally to the type of response that neonates generate against viral, bacterial, fungal and parasitic infections (Maródi, 2006). Some clinical reports demonstrate that neonatal immunity is predominantly of the Th2 type, which specifically stimulates immune tolerance and inhibits the Th1 type response, which in turn activates immune cells to control and eliminate pathogens.

This tolerance and ineffectiveness in young individuals is related to the type of cytokines that are released and circulate before and after infection, such as the immunomodulatory molecule IL-10 that negatively regulates the activation of cells such as macrophages, NK cells and $\mathrm{T}$ and $\mathrm{B}$ lymphocytes. This hypo-reactivity of antigen-presenting cells causes them to inefficiently recognise and present viral or bacterial antigens. Additionally, in neonates, the absence of specific antibodies against microorganisms and the low level of production of molecules like IFN-gamma and TNF-alpha further reduce the activation of Th1 lymphocytes (Kemp \& Campbell, 1996; Maródi, 2006; Wilson et al., 1999), and thus the cytotoxic activity and pathogen control exhibited by lymphocytes is not established. 


\subsection{Genetic background}

The species and genetic background of vectors and hosts are other determinants that can favour the dispersion of flaviviruses and neuroinfection. The enzootic life cycle of flaviviruses includes vectors and reservoirs such as birds, monkeys or other wildlife, as well as humans. Flavivirus vectors can include mosquitoes of the Aedes and Culex genera and ticks of the Ixodes genus, which transmit TBEV (Lindenbach et al., 2007). The known reservoirs for flaviviruses are birds and small mammals, which suggests that there are some species-specific characteristics that restrict the transmission of these viruses. These ecological restrictions are evident during DENV infection in some experimental infection models in mice and monkeys, which reproduce some signs of disease that manifest in infected humans. Additionally, in these models, certain symptoms associated with infection are exhibited that are uncommon in infected humans, such as neurological alterations (Tan et al., 2010), which render interpretation of the data more difficult.

Murine models commonly used to reproduce certain symptoms associated with DENV infection are mice models such as SCID (Lin et al., 1998), AG129 (lacking functional IFN- $\alpha / \beta$ and $-\gamma$ receptors) (Johnson \& Roehring, 1999; Williams et al., 2009; Tan et al., 2010) and NOD/SCID (non-obese diabetic/severe combined immunodeficient) (Bente et al., 2005; Huang et al., 2000; Mota \& Rico-Hesse, 2009), which upon being infected by DENV develop some signs of disease such as haemorrhage, thrombocytopenia and plasma leakage (Shresta et al., 2006). Nevertheless, while these models have increased our understanding of some of the cellular and molecular mechanisms involved in the development of the haemorrhagic signs observed during infection, their interpretation should be tentative given that these animals present an incomplete immune response to the virus due to their modified genomes.

With these differences in mind, other models have been established using immunocompetent animals such as C57BJ/C, ICR, A/J (Shresta et al., 2004) and Balb/C (Barreto et al., 2007) mice, which present robust immune responses to the virus, and possibly are less susceptible to infection as a result. However, these animals contract the virus and develop symptoms when infected with mouse cell- or tissue-adapted DENV or following intravenous or intracerebral inoculation with high viral titres in suckling or young adult mice (Yauch \& Sheresta, 2008; Wu-Hsieh et al., 2009). These models allow the acquisition of other data that allow a different understanding of the molecular mechanisms associated with DENV immunopathogenesis. Nevertheless, independent of the strain of animals employed, one must keep in mind that these models are experimental tools that so far only allow the in vivo reproduction of some symptoms of the very complicated disease induced by DENV.

\section{Conclusion}

The infection and pathogenesis caused by neurotropic flaviviruses is a product of a series of complex interactions between the virus and nervous tissues and is affected by viral diversity and the host's immune response and susceptibility. Therefore, it will be necessary to perform new studies with new experimental strategies to expand our knowledge and understand the interactions between flaviviruses and nervous tissue. It will be necessary to identify those factors affecting DENV and the nervous system that favour neuroinfection 
and the increasingly frequent appearance of neurological symptoms stemming from this virus. The study of this phenomenon will provide information that permits an understanding of viral pathogenesis that is of great importance for public health in tropical countries. In addition, this proposal will uncover new strategies for antiviral and vaccine research that will be useful for fighting DENV.

\section{Acknowledgment}

We are grateful to Dr. Jacqueline Chaparro-Olaya who spared her time to go through the manuscript at various stages and offered valuable suggestions. This work was funded by División de Investigaciones - Universidad El Bosque, Colciencias-Colombia (Project 130 848925267) and Universidad Nacional de Colombia.

\section{References}

An, J.; Zhou D. Kawasaki, K. \& Yasui, K. (2003). The pathogenesis of spinal cord involvement in dengue virus infection. Virchows Arch, Vol.442, No.5, (May 2003), pp. 472-81, ISSN 0945-6317

Avirutnan, P. Malasit, P. Seliger, B. Bhakdi, S. \& Husmann, M. (1998). Dengue virus infection of human endothelial cells leads to chemokine productions, complement activation, and apoptosis. J Immunol, Vol.161, No.11, (December 1998), pp. 6338-46, ISSN 0022-1767

Avirutnan ,P; Fuchs, A. Hauhart, R. Somnuke, P. Youn, S. Diamond, M. \& Atkinson, J. (2010). Antagonism of the complement component C4 by flavivirus nonstructural protein NS1. J Exp Med, Vol.207, No.4, (April 2010), pp. 793-806, ISSN 0022-1007

Banerjee, S. \& Bhat, M. (2007). Neuron-Glial interactions in blood brain barrier formation. Ann Rev Neurosci, Vol.30, (July 2007), pp. 235-58, ISSN 1545-4126

Barba-Spaeth, G.; Longman, R. Albert, M. \& Rice, C. (2005). Live attenuated yellow fever 17D infects human DCs and allows for presentation of endogenous and recombinant T cell epitopes. J Exp Med, Vol.202, No.9, (October 2005), pp. 1179-84, ISSN 0022-1007

Barreto dos Santos, FB.; Miagostovich, MP. Nogueira, RM. Edgil, D. Schatzmayr, HG. Riley, LW. \& Harris E. (2002). Complete nucleotide sequence analysis of a Brazilian Dengue Virus Type 2 Strain. Mem Inst Oswaldo Cruz. Vol.97, No.7, (October 2002), pp. 991-995, ISSN 1678-8060

Barreto, D.; Takiya, C. Schatzmayr, H. Ribeiro, R. Farias, J. \& Barth, O. (2007) Histological and ultrastructural aspects of mice lungs experimentally infected with dengue virus serotipe 2. Mem Inst Oswaldo Cruz, Vol.102, No.2 (May 2007), pp. 175-82, ISSN 1678-8060

Beasley, D.; Li, L. Suderman, \& M. Barrett, A. (2002). Mouse neuroinvase phenotype of West Nile virus strain varies depending upon virus genotype. Virology, Vol.296, No.1, (April 2002), pp. 17-23, ISSN 0042-6822

Becker, Y. (1990). Computer analysis antigenic domains and RGD-like sequences (RGWG) in the glycoprotein of flavivirus: a approach to vaccine development. Virus Genes, Vol.4, No.3, (September 1990), pp. 267-82, ISSN 0920-8569 
Ben-Nathan, D.; Huitinga, I. Lustig, S. van Rooijen, N. \& Kobiler, D. (1996). West Nile virus neuroinvasion and encephalitis induced by macrophage depletion in mice. Arch Virol, Vol.141, No.3-4, pp. 459-69, ISSN 0304-8608

Bente, D.; Melkus, M. Garcia, J. \& Rico-Hesse, R. (2005). Dengue fever in humanized NOD/SCID mice. J Virol, Vol.79, No.21, (November 2005), pp. 13797-13799, ISSN 1098-5514

Bray, M.; Men, R. Tokimatsu, I. \& Lai, C. (1998). Genetic determinant responsible for acquisition of dengue type 2-virus mouse neurovirulence. J Virol, Vol.72, No.2, (February 1998), pp. 1647-51, ISSN 1098-5514

Calabria, A.; \& Shusta, E. (2006). Blood-brain barrier genomics and proteomics: elucidating phenotype, identifying disease targets and enabling brain drug. Drug Discov Today, Vol.11, No.17-18, (September 2006), pp. 792-99, ISSN 1878-5832

Cardosa, M.; Gordon, S. Hirsch, S. Springer, T. \& Porterfield, J. (1986). Interaction of West Nile Virus with Primary Murine Macrophages: Role of Cell Activation and Receptors for Antibody and Complement. J Virol, Vol.57, No.3, (March 1986), pp. 952-959, ISSN 1098-5514

Cardoso, F.; Brites, D. \& Brito, M. (2010). Looking at the blood-brain barrier: Molecular anatomy and possible investigation approaches. Brain Res Rev, Vol.64, No.2, (May 2010), pp. 328-63, ISSN 1872-6321

Chakraborty, S.; Nazmi, A. Dutta, K. \& Basu, A. (2010). Neurons under viral attack: Victins or Warriors?. Neurochem Int. Vol.56, No.6-7, (March 2010), pp. 727-35, ISSN 18729754

Chambers, T.; \& Diamond, M. (1990). Pathogenesis of flavivirus encephalitis. Adv Virus Res, Vol.60, pp. 273-42, ISSN 0065-3527

Chambers, T.; Hahn, C. Galler, R. \& Rice, C. (1990). Flavivirus genome organization, expression and replication. Ann Rev Microbiol, Vol.44, pp. 649-88, ISSN 0066-4227

Charles, P.; Walters, E. Margolis, F. \& Johnston, R. (1995). Mechanisms of neuroinvasion of Venezuelan Equine Encephalitis Virus in the mouse. Virology, Vol.208, No.2, (April 1995), pp. 662-671, ISSN:0042-6822

Chaturvedi, U.; Dhawan, R. Khanna, M. \& Mathur, A. (1991). Breakdown of the blood-brain barrier during dengue virus infection of mice. J Gen Virol, Vol.72, No.4, (April 1991), pp. 859-66, ISSN 1465-2099

Chaturvedi, U.; Agarwal, R. Elbishbishi, E. \& Mustafa, A. (2000). Cytokine cascade in dengue hemorrhagic fever: implications for pathogenesis. FEMS Immunol Med Micro, Vol.28, No.3, (July 2000), pp. 183-88, ISSN 1574-695X

Chaturvedi, U. (2006). Tumor necrosis factor \& dengue. Indian J Med Res, Vol.123, No.1, (January 2006), pp. 11-14, ISSN 0971-5916

Chaturvedi, U.; Nagar, R. \& Shrivastava, R. (2006). Macrophage \& dengue virus: friend or foe?. Indian J Med Res, Vol.124, No.1, (July 2006), pp. 23-40, ISSN 0971-5916

Chen, C.; Liao, S. Kuo, M. \& Wang, Y. (2000). Astrocytic alteration induced by Japanese encephalitis virus infection. NeuroReport, Vol.11, No.9, (June 2000), pp. 1933-1937, ISSN 1473-558X

Chien, J.; Ong, A. \& Low, S. (2008). An unusual complication of dengue infection. Singapore Med J, Vol.49, No.12, (December 2008), pp. e340-41, ISSN 0037-5675 
Chu, J.; \& Ng, M. (2004). Interaction of West Nile Virus with alpha v beta 3 integrin mediates virus entry into cells. J Biol Chem, Vol. 279, No.24, (October 2004), pp. 54533-41, ISSN 1083-351X

Clyde, K.; Kyle, J. \& Harris, E. (2006). Recent advances in deciphering viral and host determinants of dengue virus replications and pathogenesis. J Virol, Vol.80, No.23, (August 2006), pp. 11418-31, ISSN 0022-538X

Cole, G.; \& Wisseman, C. (1969). Pathogenesis of type1 dengue virus infection in sckling, weanling and adult mice. 1. The relation of virus replication to interferon and antibody formation. Am J Epidemiol, Vol.89, No.6, (June 1969), pp. 669-80, ISSN 0002-9262

Cologma, R.; \& Rico-Hesse, R. (2003). American genotype structure decrease dengue virus output from human monocytes and dendritic cells. J Virol, Vol.77, No.7, (April 2003), pp.3929-38, ISSN 0022-538X

Courageot, M.; Catteau, A. \& Després, P. (2003). Mechanisms of dengue virus induced cell death. Adv Virus Res, Vol.60, pp. 157-86, ISSN 1557-8399

Das, S.; Laxminarayana, S. Chandra, N. Ravi, V. \& Desai, A. (2009). Heat shock protein 70 in Neuro2a cell is a putative receptor for Japanese Encephalitis virus. Virology, Vol.385, No.1, (December 2008), pp. 47-57, ISSN 1096-0341

Davis, C.; Nguyen, H. Hanna, S. Sánchez, M. Doms, R. \& Pierson T. (2006). West Nile virus discriminates between DC-SIGN and DC-SIGNR for cellular attachment and infection. J Virol, Vol. 80, No.3, (February 2006), pp. 1290-301, ISSN:0022-538X

Desprès, P.; Flamand, P. Ceccaldi, P. \& Deubel V. (1996). Human isolates of dengue type I virus induce apoptosis in mouse neuroblastoma cells. J Virol, Vol.70, No,6, (June 1996), pp. 4090-5, ISSN:0022-538X

Desprès, P.; Frenkiel, M. Caccaldi, P. Duarte dos Santos, C. \& Deubel, V. (1998). Apoptosis in the mouse central nervous system in response to infection with mouse neurovirulent dengue virus. J Virol, Vol.72, No.1, (January 1998), pp. 823-29, ISSN:0022-538X

Domingues, R.; Kuster, G. Onuki-Castro, F. Souza, V. Levi, J. \& Pannuti, C. (2008). Involvement of the central nervous system in patients with dengue virus infection. J Neurol Sci, Vol.267, No.1-2, (October 2007), pp. 36-40, ISSN 0392-0461

Duarte dos Santos, C.; Frenkiel, M. Courageot, M. Rocha, C. Vazeille, M. Wien, M. Rey, F. Deubel, V. \& Desprès, P. (2000). Determinants in the envelope E protein and viral RNA helicase NS3 that influence the induction of apoptosis in response to infection with dengue type 1 virus. Virology, Vol.274, No.2, (September 2000), pp. 292-08, ISSN 1096-0341

Ferreira, G. Figueiredo, L. Coelho, L. Junior, P. Cecilio, A. Ferreira, P. Borjardim, C. Arantes, R. Campos, M. \& Kroon, E. (2010). Dengue virus, clinical isolates show different patterns of virulence in experimental mice infection. Microbes Infection, Vol.12, No.7, (April 2010), pp. 546-54, ISSN 1769-714X

Germi, R.; Crance, J. Garin, D. Guimet, J. Lortat-Jacob, H. Ruigrok, R. Zarski, J. \& Drouet, E. (2002). Heparan sulfate-mediated binding of infectious dengue virus type 2 and yellow fever virus. Virology Vol.292, No.1, (January 2002), pp. 162-68, ISSN 10960341

Ghoshal, A.; Das, S. Ghosh, S. Mishra, M. Sharma, V. Koli, P. Sen, E. \& Basu, A. (2007). Proinflammatory mediators released by activated microglía induces neuronal death 
in Japanese encephalitis. Glia, Vol.55, No.5, (April 2007), pp. 483:496, ISSN 10981136

Griffin, D. (2003). Immune responses to RNA-Virus infections of the CNS. Nat Rev Immunol. Vol.3, No.6, (June 2003), pp. 493-502, ISSN 1474-1741

Gualano, R.; Pryor, M. Cauchi, M. Wright, P. \& Davidson, A. (1998). Identification of a major determinant of Mouse neurovirulence of dengue virus type 2 using stably cloned genomic-length cDNA. J Gen Virol, Vol.79, No.3, (March 1998), pp. 437-46, ISSN 0022-1317

Gulati, S.; \& Maheshwari, A. (2007). Atypical manifestations of dengue. Tropl Med Int Health, Vol.12, No.9, (September 2007), pp. 1087-95, ISSN 1360-2276

Guzmán, M.; Kouri, G. Valdés, L. Bravo, J. Vázquez, S. \& Halstead, S. (2002a). Enhanced severity of secondary dengue-2 infections: death rates in 1981 and 1997 Cuban outbreaks. Rev Panam Salud Publica, Vol.11, No.4, (April 2002), pp. 223-227, ISSN 1680-5348

Guzmán, M.; Kouri, G. Valdes, L. Bravo, J. Vazquez, S. \& Halstead, S. (2002b). Effect of age on outcome of secondary dengue 2 infections. Int J Infect Dis, Vol.6, No.2, (June 2002), pp. 118-24, ISSN 1878-3511

Huang, K.; Li, S. Chen, S. Liu, H. Lin, Y. Yeh, T. Liu, C. \& Lei, H. (2000). Manifestation of thrombocytopenia in dengue 2 virus infected mice. J Gen Virol, Vol.81, No.9, (September 2000), pp. 2177-82, ISSN 0022-1317

Imbert, J.; Guevara, P. Ramos-Castañeda, J. Ramos, C. \& Sotelo, J. (1994). Dengue virus infects mouse cultured neurons but not astrocytes. J Med Virol, Vol.42, No.3, (March 1994), pp. 228-33, ISSN 0146-6615

Jindadamrongwech, S.; \& Smith, D. (2004). Virus Overlay Protein Binding Assay (VOPBA) reveals serotype specific heterogeneity of dengue virus binding proteins on HepG2 human liver cells. Intervirology, Vol.47, No.6, pp. 370-3, ISSN 1423-0100

Johnson, A.; \& Roehring, J. (1999). New model for dengue virus vaccine testing. J Virol, Vol.73, No.1, (January 1999), pp. 783-86, ISSN 0022-538X

Jordan, I.; Briese, T. Fischer, N. Lau, J. \& Lipkin, W. (2000). Ribavirin inhibits West Nile virus replication and cytopathic effect in neural cells. J Infect Dis, Vol.182, No.4, (August 2000), pp. 1214-7, ISSN 1537-6613

Kawano, H.; Rostapshov, V. Rosen, L. \& Lai, C. (1993). Genetic determinants of dengue type 4 virus neurovirulence for mice. J Virol, Vol.67, No.11, (November 1993), pp. 656775, ISSN 0022-538X

Kemp, A.; \& Campbell, D. (1996). The neonatal immune system. Semin Neonatal, Vol.1, No.2, (May 1996), pp. 67-75, ISSN 1744-165X

King, N.; Getts, D. Getts, M. Rana, S. Shrestha, B. \& Kesson, A. (2007). Immunopathology of flavivirus infections. Immunol Cell Biol, Vol.85, No.1, (December 2006), pp. 33-42, ISSN 1440-1711

Kumar, R.; Tripathi, S. Tambe, J. Arora, V. Srivastava, A. \& Nag, V. (2008). Dengue encephalopathy in children in Northern India: clinical factures and comparison with non dengue. J Neurol Sci, Vol.269, No. 1-2, (January 2008), pp. 41-48, ISSN 1878-5883

Lafon, M. (2005). Rabies virus receptors. J NeuroVirol, Vol.11, No.1, (February 2005), pp. 82-7, ISSN 1355-0284 
Lee, E.; \& Lobigs, M. (2000). Substitutions at the putative receptor-binding site of an encephalitic flavivirus alter virulence and host cell tropism and reveal a role for glycosaminoglycans in entry. J Virol, Vol.74, No.19, (October 2000), pp. 8867-8875, ISSN 0022-538X

Lee, E.; \& Lobigs, M. (2002). Mechanism of virulence attenuation of glycosaminoglycanbinding variants of Japanese encephalitis virus and Murray Valley encephalitis virus. J Virol, Vol.76, No.1o, (May 2002), pp. 4901-4911, ISSN 0022-538X

Lee, E.; Hall, R. \& Lobigs, M. (2004). Common E protein determinants for attenuation of glycosaminoglycan-binding variants of Japanese encephalitis and West Nile viruses. J Virol, Vol.78, No.15, (August 2004), pp. 8271-8280, ISSN 0022-538X

Lee, E.; Wright, P. Davidson, A. \& Lobigs, M. (2006a). Virulence attenuation of Dengue virus due to augmented glycosaminoglycan-binding affinity and restriction in extraneural dissemination. J Gen Virol, Vol.87, No.10, (October 2006), pp. 2791-2801, ISSN 1465-2099

Lee, E.; Pavy, M. Young, N. Freeman, C. \& Lobigs, M. (2006b). Antiviral effect of the heparan sulfate mimetic, PI-88, against dengue and encephalitic flaviviruses. Antiviral Res, Vol.69, No.1, (November 2005), pp. 31-38, ISSN 1872-9096.

Lees, J.; Archambault, A. \& Russell, J. (2006). T-cell trafficking competence is required for CNS invasion. J Neuroimmunol, Vol.177, No.1-2, (July 2006), pp. 1-10, ISSN $1872-$ 8421

Leitmeyer, K.; Vaughn, D. Watts, D. Salas, R. Villalobos, I. Ramos, C. \& Rico-Hesse, R. (1999). Dengue virus structural differences that correlate with pathogenesis. J Virol, Vol.73, No.6, (June 1999), pp. 4738-47, ISSN 0022-538X.

Lin, C.; Lei, H. Shiau, A. Liu, H. Yeh, T. Chen, S. Liu. C, Chiu S, \& Lin Y. (2002). Endothelial cell apoptosis induced by antibodies against dengue virus nonstructural protein 1 via production of nitric oxide. J Immunol, Vol.169, No.2, (July 2002), pp. 657-64, ISSN 0022-1767

Lin, Y.; Liao, C. Chen, L. Yeh, C. Liu, C. Ma, S. Huang, Y. Kao, C. \& King, C. (1998). Study of dengue virus infection in SCID mice engrafted with human K562 cells. J Virol, Vol. 72, No. 12, (December 1998), pp. 9729-9737, ISSN 1098-5514

Lindenbach, B.; Thiel, H. \& Rice, C. (2007). Flavivirus: the virus and their replication, In: Fields Virology, David Knipe, Peter Howley, Diane Griffin, Robert A Lamb, Malcolm Martin, Bernard Roizman, Stephen Straus, pp. 1101-52, Lippincott Williams \& Wilkins, ISBN 0781760607, Philadelphia, USA

Liou, M.; \& Hsu, C. (1998). Japanese encephalitis virus is transported across the cerebral blood vessels by endocytosis in mouse brain. Cell Tissue Res, Vol.293, No.3, (September 1998), pp. 389-94, ISSN 0302-766X

Liu, T.; Llang, L. Wang, C. Liu, H. \& Chen, W. (2008). The blood-brain barrier in the cerebrum is the initial site for the Japanese Encephalitis Virus entering the central nervous system. J NeuroVirol, Vol.14, No.6, (November 2008), pp. 514-21, ISSN 1538-2443

Lobigs, M.; Usha, R. Nestorowicz, A. Marshall, I. Weir, R. \& Dalgarno, L. (1990). Host cell selection of Murray Valley encephalitis virus protein and in mouse virulence. Virology, Vol.176, No.2, (June 1990), pp. 587-95, ISSN 1096-0341

Lopes, H.; Redig, P. Glaser, A. Armien, A. \& Wuschmann, A. (2007). Clinical findings, lesions, and viral antigen distribution in great owls (Strix nebulosa) and barred 
owls (Strix varia) with spontaneous West Nile Virus infections. Avian Dis, Vol.51, No.1, (March 2007), pp. 140-5, ISSN 0005-2086

Lum, L.; Lam, S. Choy, Y. George, R. \& Harun, F. (1996). Dengue encephalitis: A true entity? Am J Trop Med Hyg, vol 54, No.3, (March 1996), pp. 256-59, ISSN 1476-1645

Luplertlop, N.; Missé, D. Bray, D. Deleuze, V. Gonzalez, J. Leardkamolkarn, V. Yssel, H. \& Veas F. (2006). Dengue-virus-infected dendritic cells trigger vascular leakage through metalloproteinase overproduction. EMBO Rep, Vol. 11, No.11, (October 2006), pp. 1176-81, ISSN 1469-3178

Malavige, G.; Ranatunga, P. Jayaratne, S. Wijesiriwardana, B. Seneviratne, S. \& Karunatilaka D. (2007). Dengue viral infections as a cause of encephalopathy. Indian J Med Microbiol, vol.25, No.2, (April 2007), pp. 143-5, ISSN 1998-3646

Marianneau, P.; Flamand, M. Deubel, V. \& Desprès, P. (1998). Apoptotic cell death in response to dengue virus infection: the pathogenesis of dengue hemorrhagic fever revisited. Clin Diagn Virol, Vol.10, No.2-3, (July 1998), pp. 113-9, ISSN 0928-0197

Maródi, L. (200065). Innate cellular immune responses in newborns. Clin Immunol, Vol.118, No.2-3, (December 2005), pp. 137-144, ISSN 1521-7035

Marques-Deak, A.; Cizza, G. \& Sternberg, E. (2005). Brain immune interactions and disease susceptibility. Mol Psychiatry, vol.10, No.3, (March 2005), pp. 239-50, ISSN 14765578

Mathew, S.; \& Pandian, J. (2010). Stroke in patients with dengue. J Stroke Cerebrovasc Dis, Vol.19, No.3, (May 2010), pp. 253-6, ISSN 1532-8511

Mathur, A.; Khanna. N, \& Chaturvedi, U. (1992). Breakdown of blood-brain barrier by virus induced cytokine during Japanese Encephalitis virus infection. Int J Exp Pathol, Vol.73, No.5, (October 1992), pp. 603-11, ISSN 1365-2613

McMinn, P.; Dalgarno, L. \& Weir, R. (1996). A comparison of the spread of Murray Valley Encephalitis Viruses of high or low neuroinvasiveness in the tissues of swiss mice after peripheral inoculation. Virology, Vol.220, No.2, (June 1996), pp. 414-423, ISSN 1096-0341

McMinn, P. (1997). The molecular basis of virulence of the encefalitogenic flaviviruses. J Gen Virol, Vol.78, No.11, (November 1997), pp. 2711-22, ISSN 1465-2099

Mellor, A.; \& Munn, D. (2006). Immune privilege: a recurrent theme in immunoregulation?. Immunol Rev, Vol.213, No.1, (October 2006), pp. 5-11, ISSN: 1600-065X

Miller, J.; de Wet, B. Martínez-Pomares, L. Radcliffe, C. Dwek, R. Rudd, P. \& Gordon, S. (2008). The Mannose Receptor Mediates Dengue Virus Infection of Macrophages. Plos Pathog, Vol.4, No.2, (February 2008), pp. e17, ISSN 1553-7374

Mishra, M.; Dutta, K. Saheb, S. Basu, A. (2009). Understanding the molecular mechanism of blood-brain barrier damage in a experimental model $\mathrm{f}$ Japanese encephalitis: Correlation with minocucline administration as a therapeutic agent. Neurochem Int, Vol.55, No.8, (July 2009), pp. 717-23, ISSN 1872-9754

Misra, U.; Kalita, J. Syam, U. \& Dhole, T. (2006). Neurological manifestations of dengue virus infection. J Neurol Sci, Vol.244, No.1-2, (March 2006), pp. 117-22, ISSN 03920461

Monath, T.; Cropp, C. \& Harrison, A. (1983). Mode of entry of a neurotropic arbovirus into the central nervous system: reinvestigation of an old controversy. Lab Invest, Vol.48, No.4, (April 1983), pp. 399-410, ISSN 1530- 0307 
Mosier, D. (2009). How HIV changes its tropism: evolution and adaptation? Curr Opin HIV AIDS, Vol.4, No.2, (March 2009), pp. 125-30, ISSN 1746-6318

Mota, J.; \& Rico-Hesse, R. (2009). Humanized mice show clinical signs of dengue fever according to infecting virus genotype. J Virol, Vol.83, No.17, (June 2009), pp. 86388645, ISSN 1098-5514

Muñoz-Fernández M.; \& Fresno, M. (1998). The role of tumor necrosis factor, interleukin 6, interferon gamma, and Inducible nitric oxide synthase in the development and pathology of the nervous system. Prog Neurobiol, Vol.56, No.3, (October 1998), pp. 307:40, ISSN 1873-5118

Ogata, A.; Nagashima, K. Hall, W. Ichikawa, M. Kimura-Kuroda, J. \& Yasui, K. (1991). Japanese Encephalitis Virus neurotropism is dependent on the degree of neuronal maturity. J Virol, Vol.65, No.2, (February 1991), pp. 880-86, ISSN 0022-538X

Pastorino, B.; Nougairède, A. Wurtz, N. Gould, E. \& de Lamballerie X. (2010). Role of host cell factors in flaviviurs infection: implications for pathogenesis and development of antiviral drugs. Antiviral Res, Vol.87, No3, (May 2010), pp. 281-94, ISSN 18729096

Petty, M.; \& Lo, E. (2002). Juctional complexes of the blood-brain barrier permeability changes in neuroinflammation. Prog Neurobiol, Vol.68, No.5, (December 2002), pp. 311-23, ISSN 1873-5118

Ramos, J.; Imbert, J. Ortega, A. \& Ramos, C. (1994). Synaptophysin and neurofilament expression in neurons infected with dengue virus. Arch Med Res, Vol.25, No.2, (Summer 1994), pp. 215-7, ISSN 0188-4409

Ramos, J.; Imbert, J. Barrón, B. \& Ramos, C. (1997). A 65-KDa trypsin-sensible membrane cell protein as a possible receptor for dengue virus in cultured neuroblastoma cells. $J$ Neurovirol, Vol.3, No.6, (December 1997), pp. 435-40, ISSN 1538-2443

Ramos, J.; Sánchez, G. Hernández, R. Baquera, J. Hernández, D. Mota, J. Ramos, J. Flores, A. \& Llausás, E. (1998). Dengue virus in the brain of a fatal case of hemorrhagic dengue fever. J Neurovirol, Vol.4, No.4, (August 1998), pp. 465-68, ISSN 1538-2443

Rempel, J.; Murray, S. Meisner, J. \& Buchmeier, M. (2004). Differential regulation of innate and adaptative immune responses in viral encephalitis. Virology, Vol.318, No.1, (January 2004), pp. 381-92, ISSN 1096-0341

Rempel, J.; Quina, A. Blakely-Gonzales, P. Buchmeier, M. \& Gruol, D. (2005). Viral induction of central nervous system innate immune responses. J Virol, Vol.79, No.7, (April 2005), pp. 4369-81, ISSN 1098-5514

Reyes del Valle, J.; Chávez-Salinas, S. Medina, F. \& Del AngelÁngel RM. (2005). Heat shock protein 90 and heat shock protein 70 are components of dengue virus receptor complex in human cells. J Virol, Vol.79, No.8, (April 2005), pp. 4557-67, ISSN 10985514

Rico-Hesse, R.; Harrison, L. Salas, R. Tovar, D. Nisalak, A. Ramos, C. Boshell, J. de Mesa, M. Nogueira, R. \& da Rosa A. (1997). Origins of dengue type 2 viruses associated with increased pathogenicity in the Americas. Virology, Vol.230, No.2, (April 1997), pp. 244-251, ISSN 1096-0341

Row, D.; Weinstein, P. \& Murray-Smith, S. (1996). Dengue fever with encephalopathy in Australia. Am J. Trop Med Hyg, Vol.54, No.3, (March 1996), pp. 253-255, ISSN 14761645 
Samuel, M. \& Diamond, M. (2006). Pathogenesis of West Nile Infection: a Balance between virulence, innate and adaptive immunity, and viral evasion. J Virol, Vol.80, No.19, (October 2006), pp. 9349-60, ISSN 1098-5514

Samuel, M.; Morrey, J. \& Diamond M. (2007a). Caspase 3 dependent cell death of neurons contributes to the pathogenesis of West Nile virus encephalitis. J Virol, Vol.81, No.6, (December 2006), pp. 2614-23, ISSN 1098-5514

Samuel, M.; Wang, H. Siddharthan, V. Morrey, J. \& Diamond, M. (2007b). Axonal transport mediates west nile virus entry into the central nervous system and induces acute flaccid paralysis. Proc Natl Acad Sci U S A, Vol.104, No.43, (October 2007), pp. 17140-45, ISSN 1091-6490

Sánchez, I.; \& Ruiz, B. (1996). A single nucleotide change in the E protein gene of dengue virus 2 Mexican strain affects neurovirulence in mice. J Gen Virol, Vol.77, No.10, (October 1996), pp. 2541-45, ISSN 1465-2099

Sánchez-Burgos, G.; Hernández-Pando, R. Campbell, I. Ramos-Castañeda, J. \& Ramos C. (2004). Cytokine production in brain of mice experimentally infected with dengue virus. Neuroreport, Vol.15, No.1, (Janaury 2004), pp. 37-42, ISSN 1473-558X

Shen, J.; T-To. S. Schrieber, L. \& King, N. (1997). Early E-Selecting, VCAM-1, ICAM-1 and late mayor histocompatibility complex antigen induction on human endothelial cells by flavivirus and comodulation of adhesion molecule expression by immune cytokines. J Virol, Vol.71, No.12, (December 1997), pp. 9323-32, ISSN 1098-5514

Shresta, S.; Kyle, J. Beatty, P. \& Harris, E. (2004). Early activation of natural killer and B cells in responses to primary dengue virus infection in A/J mice. Virology, Vol.319, No.2, (February 2004), pp. 262-73, ISSN 1096-0341

Shresta, S.; Sharar, K. Prigozhin, D. Beatty, P. \& Harris, E. (2006). Murin model for dengue virus induced lethal diseases with increased vascular permeability. J Virol, Vol.80, No.20, (October 2006), pp. 10208-17, ISSN 1098-5514

Shrestha, B.; Gottlieb, D. \& Diamond, M. (2003). Infection and injury of neurons by West Nile encephalitis virus. J Virol, Vol.77, No.24, (December 2003), pp. 13203-13, ISSN 1098-5514

Silvia, O.; Pantelic, L. Mackenzie, J. Shellam, G. Papadimitriou, J. \& Urosevic, N. (2004). Virus spread, tissue inflammation and antiviral response in brains of flavivirus susceptible and resistant mice acutely infected with Murray Valley Encephalitis Virus. Arch Virol, Vol.149, No.3, (November 2003), pp. 447-64, ISSN 1432-8798

Solomon, T. (2003). Exotic and emerging viral encephalitides. Curr opin Neurol, Vol.16, No.3, (June 2003), pp. 411-18, ISSN 1473-6551

Solomon, T. (2004). Flavivirus encephalitis. N Engl J Med, Vol.351, No.4, (July 2004), pp. 3708, ISSN 1533-4406

Sriurairatna, S.; Bhamarapravati, N. \& Phalavadhtana, O. (1973). Dengue virus infection of mice: morphology and morphogenesis of dengue type-2 in suckling mouse neurons. Infect Immun, Vol.8, No.6, (December 1973), pp. 1017-28, ISSN 1098-5522

Swarup, V.; Ghosh, J. Duseja, R. Ghosh, S. \& Basu, A. (2007). Japanese Encephalitis Virus infection decrease endogenous IL-10 production: Correlation with microglial activation and neuronal death. Neurosci Letter, Vol.420, No.2, (May 2007), pp. 14449, ISSN 1872-7972 
Tan, G.; Ng, J. Trasti, S. Schul, W. Yip, G. \& Alonso, S. (2010). A Non Mouse adapted dengue virus strain as a new model of severe dengue infection in AG129 mice. Plos Negl Trop Dis, Vol.4, No.4, (April 2010), pp. e672, ISSN 1935-2735

Tassaneetrithep, B.; Burgess, T. Granelli-Piperno, A. Trumpfheller, C. Finke, J. Sun, W. Eller, M. Pattanapanyasat, K. Sarasombath, S. Birx, D. Steinman, R. Schlesinger, S. \& Marovich, M. (2003). DC-SING (CD209) mediates dengue virus infection of human dendritic cells. J Exp Med, Vol.197, No.7, (April 2003), pp. 823-29, ISSN 1540-9538

Tio, P.; Jong, W. \& Cardosa, M. (2005). Two-dimensional VOPBA reveals laminin receptor (LAMR1) interaction with dengue virus serotypes 1, 2 and 3. Virol J, Vol.2, No.2, (March 2005), pp. 25-36, ISSN 1743-422X

Tsia, J.; Chan, K. Chang, J. Chang K, Lin, C. Huang, J. Lin, W. Chen, J. Hsien, H. Lin, S. Lin, J. Lu, P. Chen, Y. \& Lin, C. (2009). Effect of serotype on clinical manifestation of dengue fever in adults. J Microbiol Immunol Infect Vol.42, No.6 (December 2009), pp. 471-78, ISSN 1684-1182

Upanan, S.; Kuadkitkan, A. \& Smith, D. (2008). Identification of dengue virus binding proteins using affinity chromatography. J Virol Method, Vol.151, No.2, (June 2008), pp. 325-8, ISSN 1879-0984

van den Pol, A. (2006). Viral infections in the developing and mature brain. Trens Neurosci, Vol.29, No.7, (June 2006), pp. 398-06, ISSN 1878-108X

van der Schaar, H.; Rust, M. Waarts, B. van de Ende-Metselaar, H. Kuhn, R. Wilschut, J. Zhuang, X. \& Smit, J. (2007). Characterization of the early events in Dengue Virus cell entry by biochemical assays and single-virus tracking. J Virol, Vol.81, No.21, (August 2007), pp. 12019-28, ISSN 1098-5514

van der Schaar, H.; Rust, M. Chen, C. van der Ende-Metselaar, H. Wilschut, J. Zhuang, X. \& Smit, J. (2008). Dissecting the cell entry pathway of Dengue Virus by single-particle tracking in living cells. PLOS Pathogens, Vol.4, No.12, (December 2008), pp. e1000244, ISSN 1553-7374

Van Marle, G.; Antony, J. Ostermann, H. Dunhanm, C. Hunt, T. Holliday, W. Maingat, F. Urbanoswski, M. Hobman, T. Peeling, J. \& Power, C. (2007). West Nile virus induced neuroinflammation: glial infection and capsid protein-mediated neurovirulence. J Virol, Vol.420, No.20, (August 2007), pp. 144-149, ISSN 1098-5514

Verna, S.; Lo, Y. Chapagain, M. Lum, S. Kumar, M. Gurjav, U. Luo, H. Nakatsuka, A. \& Nerurkar, V. (2009). West Nile Virus infection modulates human brain microvascular endothelial cells tight junctions proteins and cell adhesion molecules transmigration across the in vitro blood brain barrier. Virology, Vol.385, No.2, (January 2009), pp. 425-33, ISSN 1096-0341

Wang, T.; Town, T. Alexopoulou, L. Anderson, J. Fikrig, E. \& Flavell, R. (2004). Toll-Like receptor 3 mediates west nile virus entry into the brain causing lethal encephalitis. Nat Med, Vol.10, No.12, (November 2004), pp, 1366-73, ISSN 1546-170X

Weiner, L.; Cole, G. \& Nathanson N. (1970). Experimental encephalitis following Peripherals inoculation of West Nile virus in mice of different ages. J Hyg (Lond), Vol.68, No. 3, (September 1970), pp. 435-46, ISSN 0022-1724

Williams, K.; Zompi, S. Beatty, P. \& Harris, E. (2009). A mouse model for studying dengue virus pathogenesis and immune response. Immunology and pathogenesis of viral hemorrhagic fevers. Ann NY Acad Sci, Vol.1171, Suppl.1, (September 2009), pp. E12-E23, ISSN 1749-6632 
Wilson, C.; Lewis, D. \& English, K. (1999). Immunity in the neonate. Semin Pediatr Infect Dis, Vol.10, No.2, (April 1999), pp. 83-90, ISSN 1045-1870

Wrona, D. (2006). Neural-immune interactions: an integrative view of the bidirectional relationship between the brain and immune systems. J Neuroimmunol, Vol.172, No.1-2, (Janaury 2006), pp. 38-58, ISSN 1872-8421

Wu-Hsieh, B.; Yen, Y. \& Chen, H. (2009). Dengue hemorrhage in a Mouse model: Immunology and pathogenesis of viral hemorrhagic fevers. Ann NY Acad Sci, Vol.1171, Suppl.1, (September 2009), pp. E42-E47, ISSN 1749- 6632

Yauch, L.; \& Sheresta S. Mouse models of dengue virus infection and disease. Antiviral Res, Vol.80, No.2, (July 2008), pp. 87-93, ISSN 1872-9096 


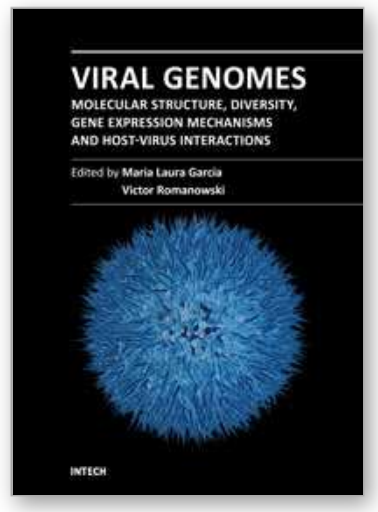

\author{
Viral Genomes - Molecular Structure, Diversity, Gene Expression \\ Mechanisms and Host-Virus Interactions \\ Edited by Prof. Maria Garcia
}

ISBN 978-953-51-0098-0

Hard cover, 302 pages

Publisher InTech

Published online 24, February, 2012

Published in print edition February, 2012

Viruses are small infectious agents that can replicate only inside the living cells of susceptible organisms. The understanding of the molecular events underlying the infectious process has been of central interest to improve strategies aimed at combating viral diseases of medical, veterinary and agricultural importance. Some of the viruses cause dreadful diseases, while others are also of interest as tools for gene transduction and expression and in non-poluting insect pest management strategies. The contributions in this book provide the reader with a perspective on the wide spectrum of virus-host systems. They are organized in sections based on the major topics covered: viral genomes organization, regulation of replication and gene expression, genome diversity and evolution, virus-host interactions, including clinically relevant features. The chapters also cover a wide range of technical approaches, including high throughput methods to assess genome variation or stability. This book should appeal to all those interested in fundamental and applied aspects of virology.

\title{
How to reference
}

In order to correctly reference this scholarly work, feel free to copy and paste the following:

Myriam Lucia Velandia and Jaime E. Castellanos (2012). Flavivirus Neurotropism, Neuroinvasion, Neurovirulence and Neurosusceptibility: Clues to Understanding Flavivirus- and Dengue-Induced Encephalitis, Viral Genomes - Molecular Structure, Diversity, Gene Expression Mechanisms and Host-Virus Interactions, Prof. Maria Garcia (Ed.), ISBN: 978-953-51-0098-0, InTech, Available from:

http://www.intechopen.com/books/viral-genomes-molecular-structure-diversity-gene-expression-mechanismsand-host-virus-interactions/flavivirus-neurotropism-neuroinvasion-neurovirulence-and-neurosusceptibilityclues-to-understanding-

\section{INTECH}

open science | open minds

\section{InTech Europe}

University Campus STeP Ri

Slavka Krautzeka 83/A

51000 Rijeka, Croatia

Phone: +385 (51) 770447

Fax: +385 (51) 686166

www.intechopen.com

\section{InTech China}

Unit 405, Office Block, Hotel Equatorial Shanghai

No.65, Yan An Road (West), Shanghai, 200040, China

中国上海市延安西路65号上海国际贵都大饭店办公楼 405 单元

Phone: +86-21-62489820

Fax: $+86-21-62489821$ 
(C) 2012 The Author(s). Licensee IntechOpen. This is an open access article distributed under the terms of the Creative Commons Attribution 3.0 License, which permits unrestricted use, distribution, and reproduction in any medium, provided the original work is properly cited. 